\title{
Effect of Cash Management Practices on the Profitability of Bottled Purified Companies Garowe and Bosaso-Puntland Somalia
}

\author{
Abdirizak Mohamed Jama ${ }^{1}$, Mohamed Samantar ${ }^{2}$, Dr. WillyMuturi ${ }^{3}$ \\ ${ }^{I}$ (Department Of Business Administration / Jomo Kenyatta University of Agriculture and Technology, Kenya \\ ${ }^{2}$ (Department Of Business Administration, Jomo Kenyatta University of Agriculture and Technology, Kenya) \\ ${ }_{3}^{3}$ (Department Of Business Administration, Jomo Kenyatta University of Agriculture and Technology, Kenya)
}

\begin{abstract}
Cash management is a key management tool seeks to establish the financial position of an organization. Cash management is keen on management of cash flow and this aims to achieve the control of cash balances by paying financial commitments ultimately resulting in meeting organizational needs. Value chain efficiency can be improved if organizations choose to control in a better way and change their financial procedures. This study will use Slovene's formula to establish the sample size of 46. Questionnaires will be used to collect data; document analysis and interviews, then correlational and regression analysis will be used. Significance will be tested at $95 \%$ confidence level and 5\% significant levels. Puntland Bottled Purified water companies are owned by local business people and deliver the products to their customers. Money flows into and out of these companies on a daily basis. This paper seeks to discuss the effect of cash control and financial performance of Bottled Purified Companies Garowe and Bosaso-Puntland Somalia. Cash flow is the life blood of all organizations and is the primary indicator of enterprise health. Cash control effect on enterprise overall performance is primarily based on extraordinary models similar to that of Baumol which identified the similarities between cash and stock management.
\end{abstract}

Keywords: Cash Management, Budget, Cash Control, Profitability and Zaka

\subsection{Background}

\section{Introduction}

Cash control entails a wide array of functions and roles which enable both individual persons and businesses organizations to process their receipts and payments transactions in a more controlled, organized and efficient way. Today, the administering of cash assets regularly uses many support services that are automated and availed by financial institutions Malcolm \& Harris (2010). Services of Cash management vary from basic checkbook balancing to making investments in bonds and other financial securities and software which are automated which enables collection of cash in a more easy fashion.

A large number of companies are experiencing negative cash flows in their operations which cause difficulties in meeting company liabilities such as payment of suppliers, staff wages and salaries and meeting deadlines for tax payments. When a company is holding cash or cash equivalents that are insufficient, interruption of normal flow of most business operations occurs. Most businesses have failed to satisfy their appetite for precautionary motive of holding cash. The theory of holding cash purely based on the motive of precaution makes an assumption that the management needs cash to over any emergency that may arise when cash flows fall below projections Smith, (2000). Firms may find it very difficult to meet unexpected needs for cash by holding cash balances as a precaution. In addition, because of inaccuracy of margins of safety by many firms, most of them end up facing financial difficulties with organizations holding cash and failing to take advantage of good unexpected investment opportunities which denies them additional investment income they could have earned. The speculative motive of holding cash is also quite difficult to satisfy. According to Wright (2002) speculative motive infers holding cash balances in order to benefits from additional opportunities that may arise such as a bargain purchase for a company or individual.

\subsection{Cash Management in Firms}

A majority of firms manage their cash balances using the following procedure; determination of the appropriate cash balance to hold and this entails assessing the tradeoff between benefit and cost of liquidity, then establishing an optimal amount of liquidity and any surplus cash is invested in short-term marketable securities for maximization of profit Ross (2003). According to Malcolm \& Harris (2010), in cash collections, some popular methods can customer payment receipts easier. Clearing houses that are automated today enable transaction of B2B cash transfers that charges payments to the customer accounts and makes payments into vendor accounts. Local banks, at a fee offer this service. According to Larrson (2000), cash management is not 
something new and firms have always sought to manage their liquid capital in the best way possible. Although management of liquid capital has always been done, cash management as a term has thrown new light in liquid capital management, cash flow management being the main area of focus. In the fifties models of cash management were pioneered birthing the idea of cash management use.

Bort (2004)noted that, for both new and growing businesses, cash management is very important. Lack of margins of safety may cause companies to suffer from cash flow problems in the case of expected financial commitments which result in companies lacking funds for expansion, innovation and growth. Hiring and retention of good employees is difficult in companies that have weak cash flow management systems Beranek, (2000)

\subsection{Purified Water Bottling companies in Somalia}

In Puntland the most notable challenges experienced in Puntland Somalia since the collapse of the central government more than two decades ago are breakdown and vandalized key institutional infrastructures, e.g. water treatment plant, boreholes, education facilities, high mortality rates migration of educated and competent people out of the country to Europe and neighboring states led to lack of adequate skilled and competent human resource force, recurrent severe drought occurrences contributed to diminished water table with consequences that led to drying of water sources reducing readily availability of raw water and cutting supplies.SME dependency on imported resources/inputs limited the productivity and inflated price, straining the economy limiting operational level along supply chain stages, insecurity generated by clan conflicts, insurgents and militia threats-reducing the ability to invest further with profits made. Key institution like the ministry for planning and economic lacking potentiality to guarantee repayment of loans borrowing and lending policy which scare aware accredited lending international institution in the post conflict state to achieve the desired changes towards a robust, flexible economic road map

\subsection{Statement of the problem}

Cash necessitates proper monitoring, protection, control and better employment Marie (2001). Efficient cash management practices are much more that prevention of bankruptcy and entail reduction of the risk a company is exposed to Maness(2002). Good cash management practices are greatly argued to an urgent need of Bottled water purifying companies. Puntland Bottled Purified water companies are owned by local business people and they rely on their employees to deliver the products to their customers such as tea shops, restaurants, Grocery shops, food stores, Hotels, government and non-governmental offices. Previous Bottle Purified Companies got bankrupt like Shifo and Xareeda water companies and the current companies are in risk of the same because timing is important even if their business was profitable at that time, they ran into problems because the payments from customers come in too slowly, and they had too many outflows while they were waiting their customers to pay.

\subsection{Objectives}

The general objective will be to determine effect of Cash Management Practice on the profitability of Bottled Purified Companies Garowe and Bosaso-Puntland Somalia. To achieve this main objective the research will establish the effect of cash budgeting by Bottled Purified Companies in Garowe and Bosaso-Puntland Somalia, evaluate the effect of cash collection on financial performance of Bottled Purified Companies Garowe and Bosaso-Puntland Somalia, investigate the effect of cash planning on financial performance of Bottled Purified Companies Garowe and Bosaso-Puntland Somalia, asses of the effect of cash control on financial performance of Bottled Purified Companies Garowe and Bosaso-Puntland Somalia.

\subsection{Baumol Model Theory}

\section{Literature Review}

Baumol model developed by using William Baumol it's far a derivative of the economic order quantity (EOQ) version. The model assists in deciding optimal cash balances to be held in organizations. It treats cash as an inventory item and buying and selling investment transactions to be the ordering fees. This aims at minimizing the fixed fee of purchasing and selling investment transactions and significantly reduce the possibility fee of holding too much unneccesary cash. Just like in EOQ Baumol is a -step components. Step one is to determine the most excellent transaction size. Step two is to determine the top of the line range of transactions in duration. Average cash holdings might be one half of the ultimate transaction size.

In the Baumol version of cash management there is a tradeoff between possibility cost or wearing fee or conserving cost \& the value of the transaction. Baumol version of cash control facilitates in figuring out a firm's most desirable cash stability beneath reality. It is drastically employed because it is beneficial for the purpose of cash management. As according to the model, cash and inventory control issues are synonymous. 
William J. Baumol evolved a version (The transactions demand for cash: An inventory Theoretic approach that is populary in inventory management \& cash control).

\subsection{Cash Budget}

Chastain (2008) argues that budgets provide financial road maps companies' consider, when planning for expenses and monitoring the cash flow all year round in the business. The cash budget is one of the common cash management tools that exist in most companies.Pindado (2004) argued that, cash budgets, can only be estimates and not actuals cash flows in spite of them being prepared on either an annual, quarterly, weekly, monthly, or even on a daily basis. Even the most accurate estimates may not be exactly correct; therefore variations in the cash budgets are almost certain.

\subsection{Cash Control}

That is the overall mind-set and actions of control regarding cash management cash inside the entity. According to Hamilton (2001) an oblivious intention of an organization is to govern and control its management of cash in a way that preserves balances of cash to a minimal stage and put extra available cash in income earing investments.Petty cash control, charges ought to be included in budgets, meaning petty cash reconciliation by an independent and impartial person. The levels and cash floats location need tobe established according to organization needs. According to Puxty (1999), it is very crucial to maintain some of the business enterprise's assets in cash due to normally recognized motives for holding cash by an organization.

\subsection{Empirical Literature Review}

Benedikt et al.,(2007) in their study on cash management guidelines for commercial banks in the U.S. and observed, increase in cash finances strategies assist the banks to obtain targeted mortgage stage. These findings are a confirmation of the overall low credit efficiency score threat through adoption of cash budget practices Abdifatah (2010) conducted a study on the link between liquidity threat and profitability of commercial banks in Kenya. The study revealed that money collection of Kenyan commercial banks is affected negatively because of the liquidity gap and firm leverage increases. Akunga (2013)did a study on the connection between liquidity threat and financial performance of business banks in Kenya. The findings of the study had been that money collection of the commercial bank in Kenya is negatively affected because of increase within the liquidity gap and leverage.Gaitho (2010)carried out a survey of cash management practices with the aid of SACCOs in Nairobi. The findings revealed that majority of the SACCOs use cash planning practices to mitigate risks as a foundation for objective credit chance appraisal. The findings revealed that money planning practices have impacted undoubtedly to their agencies with the aid of ensuring performance in carrying out its obligations and in meeting its objectives.

Ugraise (2013) studies the effect of cash control at the economic overall performance of commercial banks in Rwanda. From the study findings, cash control identity become determined to be important in ensuring profitability of Rwandan commercial banks. The cash management and cash planning were also established to be significant in organizational financial performance. Ravi (2012) did study effect of credit risk control on commercial banks profitability in Nepal by way of studying the economic report of 31 banks. The study findings revealed that money control, cash making plans and cash budgeting have a negative effect on banks' economic overall performance; however, the default price is the maximum financial predictor of economic performance. The study encouraged that the banks needed to design and formulate techniques to be able to best reduce the publicity and profitability of commercial banks.

Kargi (2011) cash control and cash budgeting is an essential in cash management. Correct monitoring and right control are crucial elements in business enterprise. This study investigates effect of cash control and budgeting control on the profitability of Nigerian food and drinks manufacturing companies. The variables encompass, cash control, cash budgeting, cash making plans, debt and income boom. Secondary data was used for the period 2000-2011. Multiple regression analytical tools were used to analyze the hypothesis. The findings reveal that money control and cash budgeting had fine and non-large courting with profitability, at the same time as debt had high quality but non-huge positive link with profitability of meals and drinks manufacturing organizations in Nigeria. Subsequently, income boom additionally had wonderful and non- significant relationship with profitability.

\section{Methodology}

The research design of this study is both a qualitative and quantitative approach targeting individuals selected from the Bottled Purified Companies in Garowe and Bosaso-Puntland. This study will use Slovene's formula to establish the sample size of 46.Questionnaires will be used to collect data; document analysis and interviews, then correlational and regression analysis will be used. Significance will be tested at $95 \%$ confidence level and 5\% significant levels. 


\section{Conclusion}

Cash flow is the life blood of all organizations and is the primary indicator of enterprise health. It is commonly mentioned as the most pressing subject of Bottled Purified Water companies. The impact of cash flow is real, immediately and, if mismanaged, absolutely unforgiving. Cash ought to be monitored, included, controlled and put to work. According to Cooke (2003) Cash is king! Just like the absence of water to a living thing, the absence of cash to the commercial enterprise implies demise slowly, torturous, bodily painful, and mentally agonizing. Earnings are a periodic measurement, calculated monthly, quarterly, and annually. Cash, on the other hand, is a daily problem. Earnings are a periodic measurement, calculated monthly, quarterly, and annually. Cash, on the other hand, is a daily problem.

Cash control effect on enterprise overall performance is primarily based on extraordinary models similar to that of Baumol which identified the similarities between cash and stock management. He extended the economic order quantity (EOQ) model to observe its implications to cash management. Cash control effect on enterprise overall performance is primarily based on extraordinary models similar to that of Baumol model.

\section{Recommendation}

Since the cash budgeting is found to significantly influence the profitability of the water Purified companies the research recommend that Purified Water Companies to engage the cash budgeting to improve their profit. The researcher also recommends that Companies need not to emphasize and put a lot of efforts of further cash control there is a measurement of improving profits.

\section{References}

[1]. Abdifatah L. Munoz (2010) the Impact of Cash Management on Cash Holdings: AQuantitativeStudy of Swedish Manufacturing SMEs, Mid Sweden University,Faculty of HumanSciences, and Department of Social Sciences.

[2]. AkungaGitagia (2013) The Regional Programme of Enterprise Development Survey, 993[16]95: Structure and Performance of Manufacturing in Kenya. London: Palgrave.

[3]. Beranek Gallagher, (2000) Analysis for Financial Decisions, 15th Edition, Irwin, Homewood.Sweden. Journal of marketing, 58, 5366.

[4]. Benedikt et al.,(2007). Customer satisfaction, market share and profitability: findings fromChastain Christopherson (2008) From Risk Taker to Risk Manager: Ten Principles for Establishing aComprehensive Risk Management System for Banks

[5]. GaithoNiazi (2010) A survey of cash management practices by SACCOs in Nairobi. UnpublishedMBAproject, University.

[6]. Hamilton Munoz (2001) Principles for the management of cash planning, Consultative Paper, Basel:Bankfor International Settlements

[7]. KargiHishamuddin (2011) Capital regulation and bank risk-taking: A note. Journal ofBanking and Finance, 13,883-89.

[8]. Larsson Kagunda (2000) Credit risk management and profitability in commercial banks in Sweden; Master's thesis submitted to University of Gothenburg, School of Business,economic and Lawort Grant (2004) Corporate cash management handbook, Warren Gorham and Lamont

[9]. Marie Moerth, (2001) The valuation of risk assets and the selection of risky investments in stockportfolios and capital budgets, Review of Economics and Statistics 47, 13-37.

[10]. Maness and John, (2002) Profitability and commercial banks' performance in Nigeria: a panelmodel Approach. Australian Journal of Business and Management Research,2 (2),31-38.

[11]. Malcolm \& Harris (2010) What is cash management? Malcolm Tatum Edited by Bronwyn Harris, Last Modified: 11 November 2010, ISBN-124884575330.

[12]. PindadoKigen (2004) 'What is a dollar worth? The market value of cash holdings', Working Paper, Georgetown University, Washington, DC

[13]. Puxty and Dodds (1999) The Concise Encyclopedia of Economics. Library of Economics andLiberty (2nd ed.) (Liberty Fund)

[14]. Ross, S.A., R.W. Westerfield and B.D. Jordan, 2003. Fundamentals of Corporate Finance.6th Edition. McGraw-Hill Irwin Publications, New York, ISBN: 0-07- 246974-9, pp: 167.

[15]. Ravi Bolten, (2012) The impact of credit risk management on financial performance ofcommercial banks in Nepal. International Journal of Arts and Commerce, 1 (5) RIA Group, New York.

[16]. Robert A. Cooke, (2003) Multi-country study of bank credit risk determinants, International Journal of Banking and Finance, 5(1), $135-152$.

[17]. Smith Gapenski, (2000) Principles of Cost Accounting, A Managerial Perspective, Fifth Edition Chatham press, London

[18]. Ugirase Nyakundi (2013) The Effect of Credit Risk Management on the FinancialPerformanceof CommercialBanks in Rwanda. Unpublished MBA thesis, Universityof Nairobi.

[19]. Wright Gillian (2002) Research Methods for Business Studies, 3rd Edition, PearsonEducation New Delhi. 